\title{
Analisis Kualitas Produk dalam Keputusan Pembelian Batik pada UKM An Nisa di Kota Jambi
}

\author{
Pupu Sopini \\ Fakultas Ekonomi Universitas Batanghari
}

\begin{abstract}
The research aims to analyse and describe the quality of batik products based on the assumptions and opinions of batik consumers in their purchasing decisions. The type of research used is a qualitative descriptive approach. The population of this research is the number of consumers of Batik An Nisa who use Batik products in 2018. While the sample withdrawal using Slovin formula with $10 \%$ precision, the sample obtained as many as 57 people with the technique of random sampling. Method of collecting data using questionnaires. The results showed that from the 7 indicators in variable product quality, the product conformity indicator is on the sub-indicator of the material used good quality shows the score of 198 which is the highest score compared to 6 indicators Other. This is very related to the target market of Batik An Nisa, where the average purchase of the product is a civil servant (PNS) with an income range of 2-3 million rupiah per month. While the lowest score of 156 is obtained on the product feature indicators a diverse pattern of motive sub can affect the quality of the product, with the results quite agreed. This gives the meaning that more motifs are certainly more and more choices of consumers to buy batik in An Nisa UKM, so that the batik become valuable for consumers.
\end{abstract}

Keywords: product quality, purchase decision.

\section{PENDAHULUAN}

Salah satu pelaku UMKM di Indonesia adalah Industri Batik yang merupakan bagian warisan karya seni budaya luhur Bangsa Indonesia dan dapat memberikan nilai positif baik dari segi ekonomi dan budaya serta memiliki keunikan serta kekhasan yang menjadikannya mampu bertahan hingga saat sekarang di tengah derasnya globalisasi dunia. Industri kerajinan batik di Indonesia sudah terbukti selama ratusan tahun dapat memberikan penghidupan ekonomi bagi para penggiatnya. Batik telah menjadi pakaian resmi nasional untuk seluruh pegawai yang bekerja baik di instansi pemerintah maupun swasta. Hampir setiap daerah di Indonesia memiliki batik dengan ciri khasnya masing-masing. Tingginya persaingan bisnis ini harus menjadi pertimbangan perusahaan atau pengrajin batik dalam meraih pelanggan guna terwujudnya tujuan perusahaan. Setiap konsumen memiliki perilaku yang berbeda-beda dalam melakukan transaksi pembelian oleh karena itu bagian pemasaran harus mempunyai strategi dalam meraih pelanggan.

Kualitas produk merupakan salah satu faktor yang menjadi pertimbangan konsumen sebelum membeli suatu produk. Kualitas di tentukan oleh sekumpulan kegunaan dan fungsinya. Termasuk didalamnya daya tahan, ketidaktergantungan pada produk lain atau komponen lain. Menurut Kotler (2008:231) kualitas produk adalah suatu sifat yang kompleks dapat diraba, termasuk bungkus, warna, harga, prestasi perusahaan, dan pengecer yang diterima oleh pembelian untuk memuaskan kebutuhan dan keinginan. Keputusan pembelian merupakan pemilihan dari dua atau lebih alternatif pilihan keputusan pembelian, artinya bahwa seseorang bisa membuat keputusan, harus tersedia beberapa alternatif pilihan. Keputusan untuk membeli bisa mengarah pada bagaimana proses dalam pengambilan keputusan tersebut itu dilakukan. Keputusan pembelian konsumen dipengaruhi oleh perilaku konsumen.

Jambi memiliki batik sendiri yang khas, dengan tema tanaman dan hewan. Motif batik Jambi yang terkenal yaitu Kepak lepas, Cendawan, Batanghari, Gong, Ayam, Matohari, Duren Pecah, Kacopiring, Kupu-kupu, Kembang duren, Keladi, Angso Duo, Kapal Sanggat dan lainnya. Proses pembuatan batik Jambi dari masa ke masa sebenarnya tidak banyak mengalami perubahan, tapi dari segi pewarnaan sekarang lebih bervariasi mulai dari pewarnaan dari bahan-bahan alami dan ada juga yang menggunaka zat kimia.. Proses pembuatan batik sendiri ada dua macam, Batik tulis yaitu batik di tulis secara manual dengan menggunakan canting, proses ini memang memakan waktu yang relatif cukup lama, kemudian Batik cap yaitu dengan menggunakan media cetak seperti stempel yang berukuran kurang lebih 20x20 cm yang terbuat dari tembaga dan kuningan proses ini bisa lebih cepat di banding batik tulis. UKM Batik Jambi An Nisa didirikan pada tahun 1999 oleh Rts. Nuryani yang selaku pemilk tunggal usaha tersebut. UKM ini terletak di Jalan Sentot Ali Basa No.90 Rt.20 Lrg. Pos Kelurahan Payo Selincah Kecamatan Paal Merah Jambi. Produk yang dihasilkan UKM An Nisa diantaranya adalah Kemeja Batik lengan pendek, Kemeja Batik lengan 
panjang, Kain dan Selendang serta berbagai jenis baju atasan khusus untuk wanita. Motif Batik yang di produksi terdiri dari motif Angso Duo, motif Durian Pecah, motif Tampuk manggis, motif Batanghari, motif Kapal sangat, dengan berbagai jenis bahan yaitu Kain Fiskus, Kain Santung, Kain Katun dan sutra. Hasil penjualan batik sangat dipengaruhi oleh keputusan pembelian konsumen, oleh karena itu kualitas produk menjadi salah satu indikator yang menentukan jumlah penjualan batik pada UKM An Nisa. Berikut adalah data perkembangan hasil penjualan Batik pada UKM AN Nisa pada Tabel 1 :

Tabel 1

Perkembangan Penjualan Batik Pada UKM An Nisa Periode 2014-2018

\begin{tabular}{rrrr}
\hline & Tahun & Total Penjualan (Rp) & Perkembangan (\%) \\
\hline 2014 & 38.540 .000 & - \\
2015 & 48.420 .000 & 2,56 \\
2016 & 58.060 .000 & 1,99 \\
2017 & 42.380 .000 & $(2,70)$ \\
2018 & 44.140 .000 & 0,41 \\
\hline
\end{tabular}

Sumber : UKM An Nisa Periode 2014-2018

Berdasarkan tabel diatas diketahui bahwa penjualan Batik pada UKM An Nisa dalam lima tahun terakhir berfluktuasi. Dimana pada tahun 2015 dapat dilihat perkembangannya sebesar 2,56\%, dan pada tahun 2016 sebesar 1,99\% dan pada tahun 2017 mengalami penurunan sebesar (2,70\%) dan pada tahun 2018 mengalami peningkatan sebesar $0,41 \%$. Salah satu indikator dalam menentukan perkembangan bisnis batik pada UKM An Nisa adalah jumlah konsumen, Semakin meningkat jumlah konsumen maka semakin sukses bisnis nya. Berikut ini adalah perkembangan jumlah konsumen batik UKM An Nisa pada Tabel 2 berikut :

Tabel 2

Perkembangan Jumlah Konsumen Batik UKM An Nisa Periode 2014-2018

\begin{tabular}{rrrr}
\hline & Tahun & & Perkembangan (\%) \\
\hline 2014 & Jumlah Konsumen (Orang) & 119 & 1,42 \\
2015 & & 136 & 0,95 \\
2016 & & 149 & $(1,40)$ \\
2017 & & 128 & 0,46 \\
2018 & & 134 & \\
\hline
\end{tabular}

Sumber : UKM An Nisa Periode 2014-2018

Berdasarkan tabel diatas maka perkembangan jumlah konsumen pada UKM An Nisa berfluktuasi dimana pada tahun 2014 jumlah konsumen mencapai 119 orang dan pada tahun 2015 jumlah konsumen meningkat menjadi 136 orang dengan perkembangannya yaitu 1,42\% dan pada tahun 2016 jumlah konsumen sebanyak 149 orang dengan perkembangannya 0,95\%. Pada tahun 2017 jumlah konsumen sebanyak 128 orang dengan penurunan persentase 1,40\% dan pada tahun 2018 jumlah konsumen sebanyak 134 orang dengan perkembangannya $0,46 \%$. Terjadinya penurunan jumlah konsumen akan mengakibatkan berkurangnya hasil penjualan dan tentu akan berdampak terhadap kinerja pemasaran produk batik. Oleh karena itu tim pemasar produk batik harus memiliki strategi pemasaran yang kuat. Untuk menunjang hal tersebut pemasar harus mengamati dan mengetahui perilaku konsumen dalam memutuskan pembelian produk batik supaya pelanggan tidak beralih ke pesaing produk yang sejenis. Proses pembuatan batik Jambi dari masa ke masa sebenarnya tidak banyak mengalami banyak perubahan, tapi dari segi pewarnaan sekarang lebih banyak mengalami perubahan mulai dari pewarnaan dari bahan-bahan alami dan ada juga yang menggunaka zat kimia dari segi motif batik jambi juga banyak mengeluarkan motif baru yang masing masing pengerajin batik di jambi mempunyai motif khas dan warna sendiri. Proses pembuatan batik sendiri ada dua macam, Batik tulis yaitu batik di tulis secara manual dengan menggunakan canting, proses ini memang memakan waktu yang relatif cukup lama, kemudian Batik cap yaitu dengan menggunakan media cetak seperti stempel yang berukuran kurang lebih 20x20 cm yang terbuat dari tembaga dan kuningan proses ini bisa lebih cepat di banding batik tulis.

Kategori produk yang dijual Batik Khas Jambi An Nisa diantaranya adalah Bahan kain Batik, Kemeja Batik lengan pendek, Kemeja Batik lengan panjang, Kain dan Selendang dan banyak juga motif Batik yang di produksi di antara lain adalah motif Angso Duo, motif Durian Pecah, motif Tampuk manggis, 
motif Batanghari, motif Kapal sangat, dan untuk bahan kain yang dipakai antara lain adalah Kain Fiskus, Kain Santung, Kain Katun dan yang terakhir adalah Kain Sutra. Untuk melakukan pemesana konsumen bisa datang langsung ke lokasi pembuatan kain batik untuk terus meningkatkan penjualan Batik Khas Jambi An Nisa harus mengutamakan kualitas dan pelayanan.

Menurut Kotler (2009:190) kualitas produk merupakan ciri dan karakteristik suatu barang atau jasa yang berpengaruh pada kemampuannya untuk memuaskan kebutuhan yang dinyatakan atau tersirat. Sedangkan menurut Kotler dan Keller (2012:143) kualitas produk adalah kemampuan suatu barang untuk memberikan hasil kerja yang sesuai bahkan melebihi apa yang diinginkan pelanggan. Kualitas produk menurut Kotler dan Amstrong (2012:236) didefinisikan sebagai sesuatu yang dapat ditawarkan ke dalam pasar untuk diperhatikan, dimiliki, dipakai, atau konsumsi sehingga dapat memuaskan keinginan atau kebutuhan. Kualitas biasanya berhubungan dengan manfaat atau kegunaan serta fungsi dari suatu produk. Kotler (2005:29) menyebutkan tujuan kualitas produk adalah mengusahakan agar barang hasil produksi dapat mencapai standar yang ditetapkan, mengusahakan agar barang hasil produksi sebagus mungkin, mengusahakan agar biaya desain dari produksi tentu menjadi sekecil mungkin, mengusahakan agar biaya produksi dapat menjadi serendah mungkin. Sumarwan (2003:322) ketika konsumen membeli suatu produk, maka ia memiliki harapan tentang bagaimana produk tersebut berfungsi (product performance). Produk akan berfungsi sebagai produk lebih baik dari yang diharapkan, inilah yang disebut sebagai diskonformasi positf (positive disconfirmation) maka konsumen akan merasa puas. Produk berfungsi seperti yang di harapkan, inilah yang disebut sebagai konfirmasi sederhana (simpe confirmation). Produk tersebut tidak memberikan rasa puas dan produk tersebut pun tidak mengecewakan konsumen. Konsumen akan memiliki perasaan netral. Produk berfungsi lebih buruk dari yang diharapkan, inilah yang disebut sebagai diskonfirmasi negatif (negative disconfirmation). Produk yang berfungsi buruk, sangat tidak sesuai dengan harapan konsumen akan menyebabkan kekecewaan sehingga konsumen merasa tidak puas.

Menurut Tjiptono (2008:25) kualitas mencerminkan semua dimensi penawaran produk yang menghasilkan manfaat (benefits) bagi pelanggan. Kualitas suatu produk baik berupa barang atau jasa ditentukan melalui dimensi-dimensinya, yaitu : (1) Kinerja (Performance), berhubungan dengan karakteristik operasi dasar dari sebuah produk; (2) Fitur (Features), karakteristik produk yang dirancang untuk menyempurnakan fungsi produk atau menambah ketertarikan konsumen terhadap produk; (3) Kehandalan (Reability), produk akan bekerja dengan memuaskan atau tidak dalam periode waktu tertentu; (4) Kesesuaian (Conformance), yaitu sejauh mana karakteristik desain dan operasi dasar dari sebuah produk memenuhi spesifikasi tertentu dari konsumen atau tidak ditemukannya cacat produk; (5) Daya Tahan (Durability), berapa lama atau umur produk yang bersangkutan bertahan sebelum produk tersebut harus diganti; (6) Estetika (Aesthetics), dimensi ini melihat kualitas suatu barang dari penampilan, corak, daya tarik, selera dan beberapa faktor lainnya mungkin menjadi aspek penting dalam kualitas; dan (7) Kesan kualitas (Percevied quality), kualitas adalah bagian terbesar dari kesan pelanggan terhadap produk dan pelayanan.

Swastha dan Irawan (2003:92) didalam buku priansa menyatakan bahwa keputusan pembelian konsumen sebenarnya merupakan kumpulan dari sejumlah keputusan, yaitu: (1) Keputusan tentang jenis produk, konsumen dapat mengambil keputusan utnuk membeli sebuah produk atau menggunakan uangnya untuk tujuan lain. Perusahaan harus memusatkan perhatiannya kepada orang-orang yang berminat membeli produk serta alternatif yang mereka pertimbangkan; (2) Keputusan bentuk produk, konsumen dapat mengambil keputusan membeli bentuk produk tertentu. Keputusan tersebut menyangkut pula ukuran, mutu, suara, corak dan sebagainya; (3) Keputusan tentang merek, konsumen harus mengambil keputusan tentang merek mana yang akan dibeli. Setiap merek mempunyai perbedaan-perbedaan sendiri; (4) Keputusan tentang penjualnya, konsumen harus mengambil keputusan di mana sebuah produk dibeli. Dalam hal ini produsen, pedagang besar, dan pengecer harus mengetahui bagaimana konsumen memilih penjual tertentu; (5) Keputusan tentang jumlah produk, konsumen dapat mengambil keputusan tentang seberapa banyak produk yang akan dibelinya pada suatu saat; (6) Keputusan tentang waktu pembelian, konsumen dapat mengambil keputusa tentang kapan ia harus melakukan pembelian. Masalah ini akan menyangkut tersedianya uang untuk membeli sebuah produk; dan (7) Keputusan tentang cara pembayaran, konsumen harus mengambil keputusan tentang metode atau cara pembayaran produk yang dibeli, apakah secara tunai atau cicilan. Keputusan tersebut akan mempengaruhi keputusan tentang penjualan dan jumlah pembelinya. 


\section{METODE}

Jenis data penelitian adalah data deskriptif kualitatif dengan menggunaka data primer yang diolah melalui kuisioner perilaku pembelian konsumen batik An Nisa. Populasi dalam penelitian ini adalah jumlah konsumen pada tahun 2018 yaitu sebanyak 134 orang. Sedangkan penarikan sampel menggunakan rumus Slovin dengan tingkat presisi $10 \%$, maka diperoleh sampel sebanyak 57 orang dengan teknik penarikan sampel random sampling. Analisis data yang digunakan dalam menganalisa data/kuesioner yang terkumpul dalam penelitian ini adalah dengan menggunakan skala likert, yaitu perhitungan dari setiap jawaban yang diberikan oleh responden dimana setiap jawaban diberi bobot nilai dan untuk selanjutnya dapat ditarik kesimpulan. Dari hasil jawaban responden maka ditentukan rentang skala untuk menentukan kategori penafsiran hasil data deskriptif pada setiap jawaban dari pertanyaan yang diajukan kepada responden dengan rumus :

$\mathrm{Rs}=((\mathrm{Rm}-\mathrm{Ri})) / \mathrm{n}$

Dimana : Rs = Rentang Skala; Rm = Skor Tertinggi; Ri $=$ Skor Terendah; $\mathrm{n}=$ Jumlah Item

Setelah diketahui rentang skala setiap kriteria/indikator, maka diperoleh kriteria penilaian : 1. Sangat Tidak Setuju, 2. Tidak Setuju, 3. Cukup Setuju, 4. Setuju dan 5. Sangat Tidak Setuju. Kemudian dihitung rata-rata (Mean) dari setiap dimensi dan indikatornya. Setelah diketahui Rata-ratanya secara keseluruhan, kemudian dilakukan analisa deskriptif berdasarkan teori pendukung dan deskripsi karakteristik responden pada Batik An Nisa.

\section{HASIL}

Jumlah responden dalam penelitian ini sebanyak 57 orang terdiri dari 35 orang perempuan dan 22 orang laki-laki. Karakteristik responden berdasarkan usia, diketahui sebagian besar responden yang membeli produk Batik Khas Jambi An Nisa berusia 21-35 tahun dengan persentase 47.3\% . Berdasarkan pekerjaan diperoleh data pegawai negeri sipil memiliki persentase dengan $28.1 \%$ dan Lain-lain dengan persentase 19.3\% Wiraswasta dengan persentase 17.5\% Karyawan Swasta dengan persentase 15.8\% Pelajar/Mahasiswa dengan persentase $12.3 \%$ dan Petani dengan persentase $7.0 \%$. Berdasarkan pendapatan perbulan responden terbanyak adalah pendapatan antara Rp.2.000.000 - Rp.3.000.000 sebanyak 40,3\%. Pendapatan Rp.1.000.000 - Rp.2.000.000 sebanyak 36,8\% dan pendapatan diatas Rp.3.000.000 sebanyak 14,2\% serta Pendapatan dibawah Rp.1.000.000 sebanyak 8,7\%. Hasil penelitian kualitas produk berdasarkan dimensi kinerja, fitur produk, kehandalan produk, kesesuaian prodak, daya tahan, estetika produk dan kesan/ persepsi kualitas. Berikut ini rekapitulasi kualitas produk berdasarkan masing-masing dimensi tersebut akan disajikan dalam Tabel 3 :

Tabel 3

Hasil Rekapitulasi Jawaban Responden Pada Kualitas Produk Batik UKM An Nisa Periode 2014-2018

\begin{tabular}{llcc}
\hline Indikator & Pernyataan & Skor & Keterangan \\
\hline Kinerja & 1. Pemilihan bahan yang alami menentukan kualitas produk & 170 & Cukup Baik \\
(Performance) & 2. Pemilihan bahan yang halus dapat menentukan kualitas produk & 167 & Cukup Baik \\
Fitur & 3. Motif yang beragam dapat mempengaruhi kualitas produk & 156 & Cukup Baik \\
(Features) & 4. Pemilihan warna yang menarik menentukan Kualitas produk & 175 & Cukup Baik \\
Kehandalan & 5. Penyesuaian Trend atau model pakaian menentukan kualitas & 189 & Cukup Baik \\
(Reability) & produk & 177 & Cukup Baik \\
& 6. Kualitas Produk menentukan kenyamanan saat dipakai & 184 & Cukup Baik \\
Kesesuaian & 7. Bisa digunakan untuk berbagai macam acara dan kegiatan & 198 & Baik \\
(Conformance) & 8. Bahan yang digunakan sangat berkualitas & 181 & Cukup Baik \\
Daya Tahan & 9. Warna yang tidak mudah luntur & 187 & Cukup Baik \\
(Durability) & 10. Bahan yang tidak mudah robek & 189 & Cukup Baik \\
Estetika & 11. Keunikan motif menentukan kualitas produk & 183 & Cukup Baik \\
(Aesthetic) & 12. Warna yang sesuai dengan motif batik & 188 & Cukup Baik \\
Persepsi Kualitas & 13. Memiliki nilai seni yang tinggi & 175 & Cukup Baik \\
(Perceived quality) & 14. Memiliki ketahanan kualitas produk & 2,519 & \\
Total & & 179,9 & Cukup Baik \\
Rata-Rata & & &
\end{tabular}

Sumber : Hasil Olahan 
Berdasarkan tabel diatas dapat diketahui bahwa pernyataan dari keseluruhan responden sebanyak 57 orang memberikan hasil skor yang berbeda-beda untuk 7 indikator kualitas produk. Indikator yang pertama mengenai kinerja/performance dengan skor 176 dan 170 maka menghasilkan rata-rata skor 161,5 artinya penilaian kinerja cukup baik. Indikator ke dua mengenai Fitur produk menghasilkan skor 156 dan 175, maka skor rata-rata dari indikator tersebut adalah 165,5 artinya fitur produk cukup baik. Indikator ke tiga yaitu kehandalan/Reability menghasilkan skor 189 dan 177, dengan rata-rata skor 183 responden menyatakan kehandalannya cukup baik. Pada indikator ke empat yaitu kesesuaian menghasilkan rata-rata 184 dan 198 dengan rata-rata skor rata-rata 191 artinya kesesuaian produk cukup baik. Indikator ke lima yaitu daya tahan menghasilkan skor 181 dan 187 dengan rata-rata skor 184, artinya daya tahan produk cukup baik. Indikator ke enam yaitu Estetika menghasilkan skor 183 dan 189 dengan rata-rata skor 186, artinya estetika dari produk batik cukup baik. Yang terakhir indikator yaitu persepsi kualitas menghasilkan skor 188 dan 175 dengan rata-rata skor 181,5 artinya persepsi kualitas produk cukup baik menurut pendapat responden. Hasil penelitian ini memberikan kesimpulan secara keseluruhan rata-rata konsumen pada Ukm Batik An Nisa menyatakan kualitas produk batik dengan rata-rata 179,9 artinya dapat dikategorikan Cukup Baik yaitu berada pada rentang skala 148,2-193,8. Indikator tertinggi berada pada dimensi kesesuaian produk dengan pernyataan bahan yang digunakan sangat berkualitas baik dengan skor 198. Berdasarkan karakteristik responden ditinjau dari profesi sebagian besar adalah Pegawai Negeri Sipil (PNS). Disamping itu hasil penelitian ini juga berhubungan dengan karakteristik responden berdasarkan jumlah pendapatan responden antara 2 juta sampe 3 juta rupiah per bulannya. Indikator terendah berada pada dimensi fitur produk dengan pernyataan motif yang beragam dapat mempengaruhi kualitas produk dengan skor 156 dan responden menyatakan cukup setuju.

\section{SIMPULAN}

1. Kualitas produk yang menjadi tolok ukur konsumen dalam memutuskan pembelian, menurut responden yang memberikan nilai tertinggi adalah pada kesesuaian produk yaitu pada indikator bahan yang digunakan berkualitas baik. Pernyataan responden tersebut sangat berhubungan dengan target pasar batik UKM An Nisa, dimana rata-rata yang membeli produk tersebut berprofesi sebagai Pegawai Negeri Sipol (PNS). Berdasarkan manfaat dan fungsinya berarti batik tersebut dipilih atau dibeli untuk digunakan sebagai seragam kantor.

2. Nilai skor yang terendah dari penelitian tersebut terdapat pada dimensi fitur produk pada pernyataan motif yang beragam dapat mempengaruhi kualitas produk, dengan hasil cukup setuju. Hal ini memberikan makna bahwa semakin banyak motif tentunya semakin banyak pilihan konsumen untuk membeli batik pada UKM An Nisa, sehingga batik tersebut menjadi bernilai bagi konsumennya. Untuk itu UKM An Nisa diharapkan terus melakukan inovasi di sisi motif batik, agar konsumen tetap setia menjadi pelanggan batik tersebut pada target pasarnya.

\section{DAFTAR PUSTAKA}

Fahmi, Irham, 2016. Perilaku Konsumen Teori dan Aplikasi, Bandung, Alfabeta.

Irawan, Deni, 2013. Analisa Pengaruh Kualitas Produk Terhadap Loyalitas Pada Pelanggan Restoran

Por Kee Surabaya. Jurnal Strategi Pemasaran, Vol.1 No.2 Tahun 2013.

Kotler, Philip dan Keller, 2012. Marketing Management, New Jersey, Prentice Hall.

Saidani, Arifin, 2012. Pengaruh Kualitas Produk dan Kualitas Layanan terhadap Kepuasan Konsumen dan Minat Beli Pada Ranch Market. Jurnal Riset Manajemen Sains Indonesia, Vol 3 No 1 Tahun 2012.

Solomon, Michael, 2011. Consumer Behavior : Buying, Having and Being, New Jersey.USA :

Pearson Pretience Hall.

Sugiyono, 2005. Metode Penelitian Kualitatif, Bandung, Alfabeta.

Sumarauw, Jacky, 2015. Analisis Kualitas produk, merek dan harga terhadap keputusan pembelian sepeda motor Suzuki Pada PT. Sinar Galesong Pratama Manado, Jurnal EMBA Vol.3 No.3 Sept 2015. Universitas Sam Ratulangi Manado.

Swasta, Basu dan Irawan, 2003. Manajemen Pemasaran Modern. Yogyakarta, Liberty Offset. Tjiptono, Fandy, 2005. Prinsip-Prinsip Total Quality Service (TQS), Yogyakarta, Andi Offset 